\title{
Circulation weather types as a tool in atmospheric, climate, and environmental research
}

\author{
Alexandre M. Ramos ${ }^{1 *}$, David Barriopedro ${ }^{2,3}$ and Emanuel Dutra ${ }^{4}$ \\ ${ }^{1}$ Instituto Dom Luiz, Faculdade de Ciências, Universidade de Lisboa, Lisbon, Portugal, ${ }^{2}$ Departamento de Física de la Tierra \\ II, Universidad Complutense de Madrid, Madrid, Spain, ${ }^{3}$ Instituto de Geociencias, Consejo Superior de Investigaciones \\ Científicas-Universidad Complutense Madrid, Madrid, Spain, ${ }^{4}$ European Centre for Medium-Range Weather Forecasts, \\ Reading, UK
}

Keywords: circulation weather types, editorial, climate variability, classifications, surface climate

OPEN ACCESS

Edited by:

Luis Gimeno,

Universidad de Vigo, Spain

Reviewed by:

Sergio M. Vicente-Serrano,

Spanish National Research Council,

Spain

${ }^{*}$ Correspondence:

Alexandre M. Ramos, amramos@fc.ul.pt

Specialty section:

This article was submitted to

Atmospheric Science,

a section of the journal

Frontiers in Environmental Science

Received: 07 May 2015

Accepted: 02 June 2015

Published: 19 June 2015

Citation:

Ramos AM, Barriopedro D and Dutra E (2015) Circulation weather types as

a tool in atmospheric, climate, and environmental research

Front. Environ. Sci. 3:44.

doi: 10.3389/fenvs.2015.00044
Classifications of circulation weather systems have a long history in meteorology and climatology. Starting with manual classifications (Hess and Brezowsky, 1952; Lamb, 1972) over specific regions of the globe, these tools (generally called "catalogs of synoptic types") were restricted mainly to weather forecasting and historical climate studies.

In the last decades, the advance of computing resources and the availability of datasets have fostered the development of fast and objective methods that process large amounts of data. Many climatological studies and applications require these data to be as simplified as possible; this is often achieved by analyzing gridded datasets (usually sea level pressure or geopotential height at different levels), and grouping the data into a relatively small number of distinct categories. Since these types are based on meteorological fields observed at a specific instant, they are also called Eulerian classifications.

Several classification methods of circulation weather types have been developed, and are currently used in a wide range of applications (Huth et al., 2008, 2010; Philipp et al., 2010). In addition, in 2002, Sheridan stated that the "Synoptic weather-typing, or the classification of weather conditions or patterns into categories, continues to be popular, and numerous methods have been developed over the past century" (Sheridan, 2002). The increasing interdisciplinary use of circulation weather types in Europe became clear when the European project "Harmonization and Applications of Weather Types Classifications for European Regions-COST733," where a wide range of classification schemes for different spatial domains were developed and compared within the scope of distinct applications. (Huth et al., 2008, 2010; Philipp et al., 2010).

In recent years, the usefulness of circulation weather type classifications has been demonstrated in a large number of scientific domains from climate (Kysely and Domonkos, 2006; Lorenzo et al., 2011), to environmental areas such as air quality (Demuzere et al., 2009) and forest fires (Kassomenos, 2010) or upwelling activity (Ramos et al., 2013). The relationship between circulation weather type classifications and high-impact weather events was also shown in extreme temperature episodes (Kysely, 2008, floods Prudhomme and Genevier, 2011), droughts (Russo et al., 2015), or even lightning activity (Ramos et al., 2011).

Automatic circulation weather type classification algorithms have also allowed exploring the variability of the atmospheric circulation over Europe during the last centuries. This has been possible by using either historical monthly mean grids going back to the eighteenth century (Beck et al., 2007) or daily fields that extend to 1871 in reanalysis products (e.g., Jones et al., 2013), to 1850 in historical data (Philipp et al., 2007) and to 1685 for some weather types (Barriopedro et al., 2014). These studies stress that changes in weather type frequencies can explain an important amount of temperature and precipitation variability. However, one must acknowledge that there are caveats such as non-stationarities in the connection between atmospheric circulation and surface 
climate. In fact, about half of the European surface climate variability (even more on long-term temporal scales) has been related to varying internal properties of some circulation weather types (the so-called within-type variations, e.g., Beck et al., 2007; Jones and Lister, 2009). Recent global warming is also manifesting in additional difficulties, as some studies have noticed a "decoupling" between atmospheric circulation patterns and the surface climate responses since the 1990s (Vautard and Yiou, 2009).

This research topic, "Circulation Weather types as a tool in atmospheric, climate, and environmental research," intends to highlight methodological advances in circulation weather types and also their applications to different research areas. The articles included in this research topic show that circulation weather types can be used not only in Europe, where they have been always more frequent, but also applied to other regions of the world. Therefore, six out of the 10 articles focus on areas outside of Europe, including central and northern America as well as southern Africa. Regarding new methodologies, a circulation type classification based upon Lagrangian air trajectories is proposed by Ramos et al. (2014a). Two different studies highlight the importance of the Lamb circulation weather types (Jenkinson and Collison, 1977) in explaining the precipitation (Ramos et al., 2014b) and drought variability (Russo et al., 2015) over the Iberian Peninsula. An automated version of the Lamb weather type classification and its relationship with precipitation is also applied with success to Saudi Arabia (El Kenawy et al., 2014). Furthermore, Hidalgo et al. (2014) shows that circulation weather types can be used to generate long term near surface climatic time series at high temporal frequencies suitable to force Soil-Vegetation-Atmosphere transfer models. Regarding tropical regions, cold surge activity over the Gulf of Mexico (Pérez et al., 2014) and low level wind regimes over Central America (Sáenz and Durán-Quesada, 2015) are addressed with

\section{References}

Bardossy, A., Pegram, G., Sinclair, S., Pringle, J., and Stretch, D. (2015). Circulation Patterns identified by spatial rainfall and ocean wave fields in Southern Africa. Front. Environ. Sci. 3:31. doi: 10.3389/fenvs.2015.00031

Barriopedro, D., Gallego, D., Álvarez-Castro, M. C., García-Herrera, R., Wheeler, D., Peña-Ortiz, C., et al. (2014). Witnessing North Atlantic westerlies variability from ships' logbooks (1685-2008). Clim. Dyn. 43, 939-955. doi: 10.1007/s00382-013-1957-8

Beck, C., Jacobeit, J., and Jones, P. D. (2007). Frequency and within-type variations of large-scale circulation types and their effects on low-frequency climate variability in Central Europe since 1780. Int. J. Climatol. 27, 473-491. doi: 10.1002/joc. 1410

Demuzere, M., Trigo, R. M., Vila-Guerau de Arellano, J., and van Lipzig, N. P. M. (2009). The impact of weather and atmospheric circulation on O3 and PM10 levels at a rural mid-latitude site. Atmos. Chem. Phys. 9, 2695-2714. doi: 10.5194/acp-9-2695-2009

El Kenawy, A. M., McCabe, M. F., Stenchikov, G. L., and Raj, J. (2014). Multidecadal classification of synoptic weather types, observed trends and links to rainfall characteristics over Saudi Arabia. Front. Environ. Sci. 2:37. doi: 10.3389/fenvs.2014.00037

Hess, P., and Brezowsky, H. (1952). Katalog der Großwetterlagen Europas (catalog of the European large scale weather types). Ber. Dt. Wetterd. US-Zone $33,39$. a circulation weather types approach. Finally, three papers focus on the Southern Hemisphere. Bardossy et al. (2015) explores Fuzzy Rule Based Circulation Patterns to identify different spatial rainfall and ocean wave fields in Southern Africa. Moron et al. (2015) uses a cluster analysis to characterize the variability of circulation weather types across the Maritime Continent. Finally, a synoptic climatology of heavy rain events in the Lake Eyre and Lake Frome catchments is presented by Pook et al. (2014).

During the last few decades, circulation weather type' classifications have been extremely useful to gain insight of the atmospheric processes at the synoptic scale, but also studying the relationship between atmospheric circulation and surface climate variability. As proven in this research topic, the use of circulation weather types' classifications is also becoming frequent to explore climate variability in regions outside Europe. Regarding methodologies, the use of nonlinear methods such as the self-organizing maps (Sheridan and Lee, 2011) is becoming popular, and the introduction of new methodologies, such as the merging weather types and Lagrangian transport presented in the research topic (e.g., Ramos et al., 2014a) is also expected.

Circulation weather types' classifications and their applications will continue to play a fundamental role in characterizing and understanding current and future changes of large-scale circulation and their local impacts in different areas of environmental sciences.

\section{Acknowledgments}

AR was supported by the Portuguese Science Foundation (FCT) through a postdoctoral grant (FCT/DFRH/SFRH/BPD/84328/ 2012). This work has been partly supported by Iberdrola Renovables under Contract 4502746576.
Hidalgo, J., Masson, V., and Baehr, C. (2014). From daily climatic scenarios to hourly atmospheric forcing fields to force Soil-Vegetation-Atmosphere transfer models. Front. Environ. Sci. 2:40. doi: 10.3389/fenvs.2014.00040

Huth, R., Beck, C., Phillipp, A., Demuzere, M., Ustrnul, Z., Cahynová, M., et al. (2008). Classifications of atmospheric circulation patterns: recent advances and applications. Trends Dir. Clim. Res. Ann. N.Y. Acad. Sci. 1146, 105-152. doi: 10.1196/annals.1446.019

Huth, R., Beck, H., and Tveito, O. E. (2010). Preface of classifications of atmospheric circulation patterns-theory and applications. Phys. Chem. Earth. 35, 307-308. doi: 10.1016/j.pce.2010.06.005

Jenkinson, A. F., and Collison, F. P. (1977). An Initial Climatology of Gales Over the North Sea, Synoptic Climatol. Branch Memo. 62. Bracknell: Meteorol. Off.

Jones, P. D., Harpham, C., and Briffa, K. R. (2013). Lamb weather types derived from Reanalysis products. Int. J. Climatol. 33, 1129-1139. doi: 10.1002/ joc. 3498

Jones, P. D., and Lister, D. H. (2009). The influence of the circulation on surface temperature and precipitation patterns over Europe. Clim. Past 5, 259-267. doi: $10.5194 / \mathrm{cp}-5-259-2009$

Kassomenos, P. (2010). Synoptic circulation control on wild fire occurrence. Phys. Chem. Earth. 35, 544-552. doi: 10.1016/j.pce.2009.11.008

Kysely, J. (2008). Influence of the persistence of circulation patterns on warm and cold temperature anomalies in Europe: analysis over the 20th century. Glob. Planet. Change 62, 147-163. doi: 10.1016/j.gloplacha.2008. 01.003 
Kysely, J., and Domonkos, P. (2006). Recent increase in persistence of atmospheric circulation over Europe: comparison with long-term variations since 1881. Int. J. Climatol. 26, 461-483. doi: 10.1002/joc.1265

Lamb, H. H. (1972). British Isles weather types and a register of daily sequence of circulation patterns, 1861-1971. Geophys. Memoir. 116, 85L.

Lorenzo, M. N., Ramos, A. M., Taboada, J. J., and Gimeno, L. (2011). Changes in present and future circulation types frequency in Northwest Iberian Peninsula. PLoS ONE 6:e16201. doi: 10.1371/journal.pone.0016201

Moron, V., Robertson, A. W., Qian, J.-H., and Ghil, M. (2015). Weather types across the Maritime Continent: from the diurnal cycle to interannual variations. Front. Environ. Sci. 2:65. doi: 10.3389/fenvs.2014.00065

Pérez, E. P., Magaña, V., Caetano, E., and Kusunoki, S. (2014). Cold surge activity over the Gulf of Mexico in a warmer climate. Front. Earth Sci. 2:19. doi: 10.3389/feart.2014.00019

Philipp, A., Bartholy, J., Beck, C., Erpicum, M., Esteban, P., Fettweis, R., et al. (2010). Cost733cat-a database of weather and circulation type classifications. Phys. Chem. Earth 35, 360-373. doi: 10.1016/j.pce.2009.12.010

Philipp, A., Della-Marta, P. M., Jacobeit, J., Fereday, D. R., Jones, P. D., Moberg, A., et al. (2007). Long-term variability of daily North Atlantic-european pressure patterns since 1850 classified by simulated annealing clustering. J. Climate 20, 4065-4095. doi: 10.1175/JCLI4175.1

Pook, M. J., Risbey, J. S., Ummenhofer, C. C., Briggs, P. R., and Cohen, T. J. (2014). A synoptic climatology of heavy rain events in the Lake Eyre and Lake Frome catchments. Front. Environ. Sci. 2:54. doi: 10.3389/fenvs.2014.00054

Prudhomme, C., and Genevier, M. (2011). Can atmospheric circulation be linked to flooding in Europe? Hydrol. Process. 25, 1180-1190. doi: 10.1002/hyp.7879

Ramos, A. M., Cordeiro Pires, A., Sousa, P. M., and Trigo, R. M. (2013). The use of circulation weather types to predict upwelling activity along the Western Iberian Peninsula coast. Cont. Shelf. Res. 69, 38-51. doi: 10.1016/j.csr.2013.08.019

Ramos, A. M., Cortesi, N., and Trigo, R. M. (2014b). Circulation weather types and spatial variability of daily precipitation in the Iberian Peninsula. Front. Earth Sci. 2:25. doi: 10.3389/feart.2014.00025
Ramos, A. M., Ramos, R., Sousa, P., Trigo, R. M., Janeira, M., and Prior, V. (2011). Cloud to ground lightning activity over Portugal and its association with circulation weather types. Atmos. Res. 101, 84-101. doi: 10.1016/j.atmosres.2011.01.014

Ramos, A. M., Sprenger, M., Wernli, H., Durán-Quesada, A. M., Lorenzo, M. N., and Gimeno, L. (2014a). A new circulation type classification based upon Lagrangian air trajectories. Front. Earth Sci. 2:29. doi: 10.3389/feart.2014.00029

Russo, A. C., Gouveia, C. M., Trigo, R. M., Liberato, M. L. R., and DaCamara, C. C. (2015). The influence of circulation weather patterns at different spatial scales on drought variability in the Iberian Peninsula. Front. Environ. Sci. 3:1. doi: $10.3389 /$ fenvs.2015.00001

Sáenz, F., and Durán-Quesada, A. (2015). A climatology of low level wind regimes over Central America using a weather type classification approach. Front. Earth Sci. 3:15. doi: 10.3389/feart.2015.00015

Sheridan, S. C. (2002). The redevelopment of a weather-type classification scheme for North America. Int. J. Climatol. 22, 51-68. doi: 10.1002/joc.709

Sheridan, S. C., and Lee, C. C. (2011). The self-organizing map in synoptic climatological research. Prog. Phys. Geogr. 35, 109-119. doi: $10.1177 / 0309133310397582$

Vautard, R., and Yiou, P. (2009). Control of recent European surface climate change by atmospheric flow. Geophys. Res. Lett. 36, L22702, doi: 10.1029/2009GL040480

Conflict of Interest Statement: The authors declare that the research was conducted in the absence of any commercial or financial relationships that could be construed as a potential conflict of interest.

Copyright (c) 2015 Ramos, Barriopedro and Dutra. This is an open-access article distributed under the terms of the Creative Commons Attribution License (CC BY).

The use, distribution or reproduction in other forums is permitted, provided the original author(s) or licensor are credited and that the original publication in this journal is cited, in accordance with accepted academic practice. No use, distribution or reproduction is permitted which does not comply with these terms. 